\title{
Revised chronology for late Pleistocene Mono Lake sediments based on paleointensity correlation to the global reference curve
}

\author{
Susan H. Zimmerman ${ }^{a, *}$, Sidney R. Hemming ${ }^{\text {a,b }}$, \\ Dennis V. Kent ${ }^{b, c}$, Stephanie Y. Searle ${ }^{a}$ \\ a Department of Earth and Environmental Sciences, Columbia University, New York, NY 10027, USA \\ ${ }^{\mathrm{b}}$ Lamont-Doherty Earth Observatory of Columbia University, Palisades, NY 10964, USA \\ c Department of Geological Sciences, Rutgers University, Piscataway, NJ 08854, USA
}

Received 2 May 2006; received in revised form 12 September 2006; accepted 13 September 2006

Available online 25 October 2006

Editor: M.L. Delaney

\begin{abstract}
Lakes are highly sensitive recorders of climate processes, but are extremely difficult to correlate precisely to ice-core and marine records, especially in the absence of reliable radiocarbon dates. Relative paleointensity (RPI) of Earth's magnetic field is an independent method of correlating high-resolution climate records, and can be applied to both marine and terrestrial sediments, as well as (inversely) correlated to the cosmogenic nuclide records preserved in ice cores. Here we present the correlation of an RPI record from Mono Lake, California to GLOPIS, the Global PaleoIntensity Stack, which increases the age estimation of the basal Mono Lake sediments by $>20000 \mathrm{yr}(20 \mathrm{kyr})$, from $\sim 40 \mathrm{ka}$ (kyr before present) to $67 \mathrm{ka}$. The Mono Lake sediments thus preserve paleoclimatic records of most of the last glacial period, from 67 to $14 \mathrm{ka}$. In addition, the paleointensity-based age of $40 \mathrm{ka}$ for the geomagnetic excursion preserved at Mono Lake indicates that this is a record of the global Laschamp excursion.
\end{abstract}

(C) 2006 Elsevier B.V. All rights reserved.

Keywords: paleointensity; GLOPIS; argon; Great Basin; Mono Lake excursion; Laschamp

\section{Introduction}

Knowledge of the variability of terrestrial climate is critical to human society, but accurate prediction of future climate requires an understanding of the mechanisms controlling the system, and the amplitude and patterns of variation which are possible. Lakes are an ideal terrestrial archive for creating descriptions of regional climates, as they occur at all latitudes and

\footnotetext{
* Corresponding author. Tel.: +1 845365 8905; fax: +1 845365 8155.

E-mail address: herrzim@1deo.columbia.edu (S.H. Zimmerman).
}

altitudes and act as spot recorders of primary atmospheric parameters such as temperature and precipitation. Lake sediments also cover a wide range of ages, from extremely high-resolution Holocene records to continuous multi-million-year records, and are deposited across a broad spectrum of hydrological, sedimentological, chemical, and biological settings. However, difficulties in dating lake records at high resolution and precision have limited their use for global study of abrupt climate changes.

The development of a reference paleointensity curve for the Earth's magnetic field opens up new possibilities for the correlation of lacustrine paleoclimate records to 
marine and ice-core archives. We have created and correlated a new paleointensity record from Mono Lake, California, to GLOPIS, the Global PaleoIntensity Stack [1], to create a high-resolution, GISP2-based chronology for the late Pleistocene sediments preserved in the Mono Basin. In so doing, we reinforce the suitability of glacial sediments from plutonic terrains for paleomagnetic work, and demonstrate the robustness of the paleointensity method in unoriented samples from exposed outcrops.

\section{Geologic setting}

Mono Lake $\left(38^{\circ} \mathrm{N}, 119^{\circ} \mathrm{W}\right)$ is located on the western edge of the Great Basin (Fig. 1), where hydrologicallyrestricted basins situated near the mountains of the Sierra Nevada, Coast Ranges, Cascades, and Basin and Range are ideal recorders of paleoclimatic conditions. Moreover, the unusually close proximity of Mono Lake to the Sierran canyons makes Mono Lake a particularly important recorder of both hydrological and glacial variability during the last glaciation. In addition to paleoclimate records, the Wilson Creek Formation sediments are the type location for the "Mono Lake Excursion" first described by Denham and Cox [2] and
Liddicoat and Coe [3], and now commonly used as a time marker in distant paleoclimatic records [4-6]. Thus, a revised chronology for the Wilson Creek Formation has broad implications for paleoclimatic, paleomagnetic, and chronostratigraphic studies.

\subsection{Stratigraphy}

The Wilson Creek Formation, first named and described in the thesis of Lajoie [7], is a sequence of deeplake silts deposited during the late Pleistocene Epoch, when the Mono Basin and many others in the Great Basin contained large lakes, such as Lake Lahontan of western Nevada and Lake Bonneville of central Utah. The sediments are primarily silt-sized glacial flour eroded from the plutons and roof pendants of the Sierra Nevada canyons by Pleistocene valley glaciers, and deposited under quiet conditions in a relatively deep lake. In the type section, located in the Wilson Creek canyon close to the Sierran front, $\sim 7 \mathrm{~m}$ of lake sediments overlie crudelyimbricated alluvial gravels. Interbedded with the lake silts are eighteen rhyolitic ashes, and one basaltic ash erupted from Black Point (Fig. 1). These were numbered (1-19, top to bottom) and bundled into five distinctive sequences, termed Marker Sequences A (youngest)-E

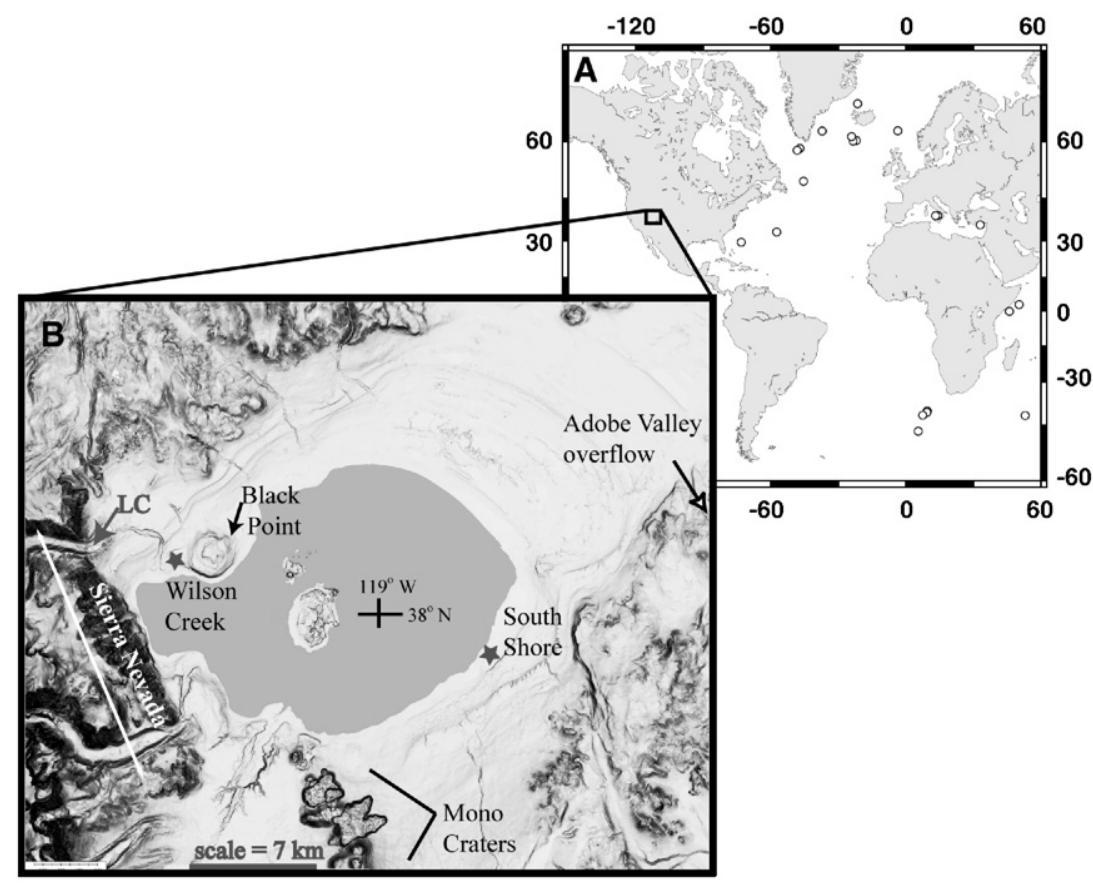

Fig. 1. Location maps of the cores included in the GLOPIS stack and the major features of the Mono Basin. A: Locations of 24 marine sediment cores comprising the GLOPIS paleointensity curve [1]. B: Mono Lake basin, showing the locations of two outcrops of the Wilson Creek Formation sampled for this study (stars); the Wilson Creek type section at the foot of the Sierra Nevada mountains, and the South Shore cliffs located $\sim 20 \mathrm{~km}$ to the east. The Mono Craters may be a source of the eighteen rhyolitic ashes in the Wilson Creek Formation; Black Point is the source of the basaltic Ash 2. LC indicates Lundy Canyon; cross marks $38^{\circ} \mathrm{N}, 119^{\circ} \mathrm{W}$. 
(oldest) by Lajoie [7] (Fig. 2), and allow very accurate correlation between the type section and other outcrops around the basin. The occurrence of these ashes in discrete layers with sharp boundaries testifies to the dominantly low-energy conditions under which the sediments were deposited.

\subsection{Chronology}

\subsubsection{Published age constraints}

Because of the usefulness of the radiocarbon system for dating late Pleistocene material, and the abundance of organic (ostracode) and inorganic (tufa) carbonate in the Mono Basin, most of the age control on the Wilson Creek Formation is based on carbonate ${ }^{14} \mathrm{C}$ dates. All three previously-reported data sets are shown in Fig. 2, converted to calendar years using Fairbanks et al. [8], and uncorrected for reservoir effects for simplicity of comparison.

Lajoie [7] calculated an age of $12.5-22.9\left({ }^{14} \mathrm{C}\right) \mathrm{ka}$ for the Wilson Creek Formation, based on two radiocarbon dates measured on ostracodes from the type section

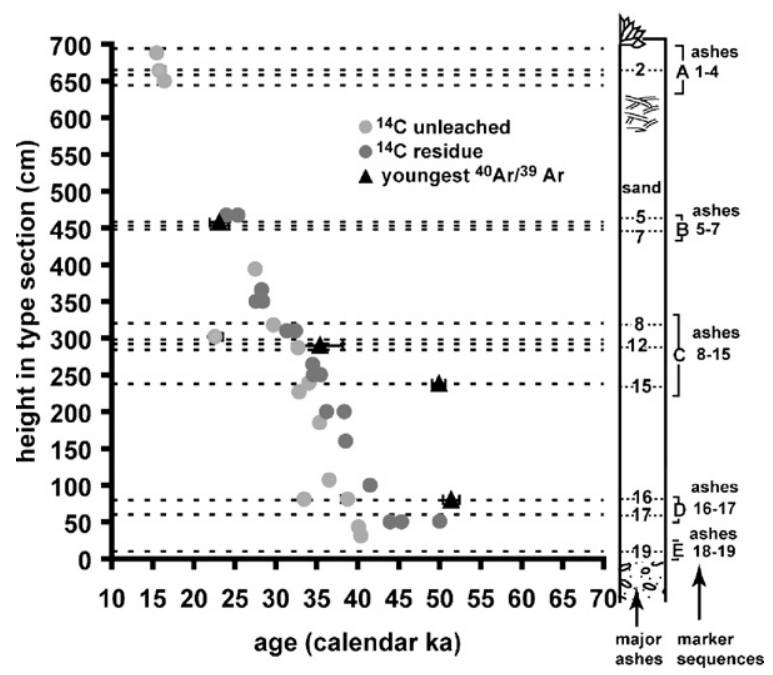

Fig. 2. Published radiocarbon (circles) and ${ }^{40} \mathrm{Ar} /{ }^{39} \mathrm{Ar}$ (triangles) constraints on the age of the Wilson Creek Formation. Unleached ${ }^{14} \mathrm{C}$ dates of Lajoie [7] and Benson et al. [9] (light circles) and leached ${ }^{14} \mathrm{C}$ dates of Kent et al. [10] (dark circles) are on ostracodes and inorganic tufa balls; all are corrected to calendar years using the calibration of Fairbanks et al. [8]. Analytical errors are mostly within the size of the symbols, and no reservoir correction has been applied to any of these data, due to extreme uncertainty in the magnitude changes through time. Single-crystal ${ }^{40} \mathrm{Ar} /{ }^{39} \mathrm{Ar}$ analyses (triangles = youngest population) of Chen et al. [12](Ashes 5 and 12) and Kent et al. [10] (Ashes 15 and 16) revealed multiple age populations indicating contamination with older (un-reset) xenocrysts. Horizontal dashed lines indicate ash beds, referenced to stratigraphic column modified from Lajoie [7], with ash numbers and marker sequences indicated.
(Fig. 2). Additional radiocarbon dates on carbonates were published by Benson et al. [9], which increased the age estimate of the base of the Formation to $36\left({ }^{14} \mathrm{C}\right) \mathrm{ka}$ (Fig. 2). These authors, however, acknowledged the unreliability of ${ }^{14} \mathrm{C}$ ages on Great Basin carbonates beyond $20 \mathrm{ka}$, and suggested that these ages be considered minimum limits. Kent et al. [10] and Hajdas et al. [11] performed partial-leaching experiments on Mono Lake carbonates, and found the offset between leached and unleached ages to be as much as $6 \mathrm{kyr}$ in the oldest Wilson Creek samples. Finding no plateaus in the age with fraction leached, both sets of authors concluded that even the oldest apparent ${ }^{14} \mathrm{C}$ ages represent minimum estimates of the true age.

Chen et al. [12] sought to extend the application of ${ }^{40} \mathrm{Ar} /{ }^{39} \mathrm{Ar}$ dating of ashes into the late Pleistocene by dating multiple samples of individual sanidines from two of the Wilson Creek Formation ashes (Ashes 5 and 12 of Lajoie's original terminology; note that the ash layers were counted bottom to top by Chen et al. [12]). They found that each ash contained multiple age populations, and concluded that the ashes were contaminated by older xenocrysts. The true age of the ashes must be no older than the youngest reliable age measured, and the youngest populations were in reasonable agreement with calendar-corrected radiocarbon ages. Kent et al. [10] applied ${ }^{40} \mathrm{Ar} /{ }^{39} \mathrm{Ar}$ to sanidines from three additional Wilson Creek Formation ashes (Ashes 8, 15, and 16 of Lajoie), and also found xenocrystic populations to be a problem. In addition, Kent et al. [10] found the youngest population of $\mathrm{Ar} / \mathrm{Ar}$ ages for each ash to be $6 \mathrm{kyr}$ to $>700 \mathrm{kyr}$ older than the best ${ }^{14} \mathrm{C}$ estimates.

Collectively, these studies indicate that a maximum limit of the age of deposition is provided by the youngest ${ }^{40} \mathrm{Ar} /{ }^{39} \mathrm{Ar}$ population measured, and the radiocarbon ages of even leached carbonates provide only a minimum age limit. The maximum constraints from Ar-dating and the minimum constraints from ${ }^{14} \mathrm{C}$-dating agree well back to $\sim 32$ ka when applied to the Wilson Creek Formation; however, they diverge by 10-20 kyr at the base of the section (Fig. 2).

\subsubsection{New Ar/Ar ages}

Here we report new ${ }^{40} \mathrm{Ar} /{ }^{39} \mathrm{Ar}$ results for Ash 16, measured on sanidines that were picked from crushed pumice fragments. We performed these analyses to test the hypothesis that sandines embedded in pumice would be most likely to have their Ar/Ar system re-set by the eruption which produced a particular ash layer, thereby minimizing the number of un-reset xenocrysts included in the measurements. Therefore, we sieved a bulk sample of Ash 16 from the South Shore outcrop at $200 \mu \mathrm{m}$, 
crushed the pumice gently with mortar and pestle, and picked individual sanidines for analysis in the $\mathrm{Ar}$ Geochronology Lab at Lamont-Doherty Earth Observatory (LDEO). Results and details of analyses are given in Supplemental Table 1.

\subsection{Paleomagnetics}

The paleomagnetic properties and records of the Wilson Creek Formation were first studied by Denham and Cox [2] during a search for the Laschamp excursion, which was then considered to be between $8.7\left({ }^{14} \mathrm{C}\right)$ and 20 (calendar) ka [13]. Polished sections and loose grain mounts prepared for that study showed fine-grained magnetite to be the dominant magnetic carrier. Although no geomagnetic reversal was found in the studied section, the authors did report unusual steep directions just above Ash 15, at $\sim 24\left({ }^{14} \mathrm{C}\right) \mathrm{ka}$, which was then regarded as significantly older than the age of the Laschamp excursion.

Liddicoat and Coe [3] re-sampled that part of the section at higher resolution, and discovered a more extreme directional change, to shallow inclinations just below Ash 15. They named the feature the Mono Lake Excursion, and reported its age at 25 to $24\left({ }^{14} \mathrm{C}\right) \mathrm{ka}$. In an odd twist of timing, new $\mathrm{K}-\mathrm{Ar}[14,15], \mathrm{Ar} / \mathrm{Ar}$ [15], $\mathrm{Th} / \mathrm{U}$ [16], and thermoluminescence [14,17] dates published at about the same time shifted the Laschamp excursion to the range of 32 to 50 (calendar) ka, thus making the excursion identified at Mono Lake by Liddicoat and Coe [3] significantly younger than the Laschamp.

Benson et al. [18] recently argued that radiocarbon dates on bulk organic carbon from Pyramid Lake sediments could be used to date the Mono Lake excursion, based on correlation of Mono Lake Ash 15 and the Carson Sink ash bed identified at Pyramid Lake. However, gross geochemical similarity of ashes in separate locations, in this case based mostly on trace-element composition, allows but does not require that the ashes represent the same event. Further, the $>90^{\circ}$ change in inclination which is diagnostic of the Mono Lake excursion has not been identified in any sequence at Pyramid Lake or Carson Sink $[19,20]$, leaving the stratigraphic location of the excursion in those two basins in doubt.

The type section of the Laschamp excursion, the Laschamp and Olby lava flows of the French Massif Central, has recently been re-dated by $\mathrm{K}-\mathrm{Ar}$ and ${ }^{40} \mathrm{Ar} /{ }^{39} \mathrm{Ar}$, resulting in an age of $40.4 \pm 2.0 \mathrm{ka}$ [21], consistent with the marine sediment and GISP2 age estimations [22]. The age of the Mono Lake excursion is currently constrained by a radiocarbon minimum age of
34.2 (calendar) ka and an ${ }^{40} \mathrm{Ar} /{ }^{39} \mathrm{Ar}$ maximum age of $49.9 \pm 0.8 \mathrm{ka}$ [10], with the younger age long assumed to be correct. This apparent difference in age between the Laschamp and Mono Lake excursions has had farreaching implications for our understanding of geomagnetic field behavior, as well as climate teleconnections between the Great Basin and North Atlantic [23] and Greenland [24] records, and can be resolved only by testing the chronology of the Wilson Creek Formation, the type section of the Mono Lake excursion.

The reproducibility of the paleomagnetic directional record in the Wilson Creek Formation was confirmed by high-resolution sampling by Lund et al. [25] at four outcrops around the basin, including the type and South Shore sections studied here. Outside of the excursion interval, inclination and declination vary about the expected dipole values, and paired sections sampled $1 \mathrm{~m}$ apart in each of the four outcrops produced virtually identical results. Together, these three comprehensive studies $[2,3,25]$ indicate that the Wilson Creek sediments are stable, faithful recorders of the ancient geomagnetic field, likely due to the abundance of primary, fine-grained magnetite eroded from the igneous and metamorphic rocks of the Sierran canyons by glacial abrasion. Thus they should also be excellent candidates for a high-fidelity record of paleo-field intensity.

\section{Mono Basin relative paleointensity (RPI)}

\subsection{Sampling and measurements}

Two outcrops of the Wilson Creek Formation were sampled for this study: the type section, on the northwest side of the lake in the late Pleistocene drainage of Lundy Canyon, and the South Shore section, exposed in bluffs on the southeast side of the basin (Fig. 1). The type section was sampled continuously at $2 \mathrm{~cm}$ spacing from Ash 8 to the alluvial gravels below Ash 19. The South Shore outcrop is much more accessible in the upper part of the section, but is strongly deformed below Ash 17 due to local slumping, and thus was sampled between Ashes 7 and 17. Paleomagnetic samples were prepared by wedging a weighed, unoriented chunk of consolidated bulk sediment into a standard plastic sample box, which was marked with an arrow to maintain uniformity of orientation throughout the multiple magnetic measurements. A total of 554 samples were measured, 215 from the type section and 339 from the South Shore.

All measurements were made in the LDEO paleomagnetics laboratory: low-field magnetic susceptibility $(k)$ was measured on a Bartington MS2 system, and Natural, Anhysteretic, and Isothermal Remnant 
Magnetizations (NRM, ARM, and IRM) on a 2G Enterprises Model 760 cryogenic magnetometer in the LDEO shielded room. ARM was imparted in a DC bias field of $0.1 \mathrm{mT}$ with a peak AF field of $100 \mathrm{mT}$. NRM and ARM of all samples were demagnetized at 10, 20, 30 , and $40 \mathrm{mT}$ steps. Step-wise IRM up to $2500 \mathrm{mT}$ was induced in a representative set of 47 samples (total from both outcrops) using an ASC pulse magnetizer, and 25 of these samples were then AF demagnetized to either 40 or $99 \mathrm{mT}$ in $10 \mathrm{mT}$ steps. Due to the uniformity of the acquisition curves (Fig. S1), all other samples were given an IRM at $500 \mathrm{mT}$, well above saturation, and demagnetized at $40 \mathrm{mT}$.

\subsection{Rock magnetic properties}

In a review of sedimentary paleointensity, Tauxe [26] proposed that sediments for paleointensity studies be limited to those where the main remanence carrier is magnetite of grain size between 1 and $15 \mu \mathrm{m}$, with a concentration variation of an order of magnitude or less. In the Wilson Creek Formation sediments, IRM acquisition curves (Fig. S1) show that $>95 \%$ of the saturation IRM (SIRM) was acquired by $300 \mathrm{mT}$, confirming the dominance of magnetite found by the earlier studies $[2,3,25]$. Variations in the concentration-dependent parameters $k$, ARM, and SIRM (Fig. 3) are within acceptable ranges [26], and the grain-size dependent ratio $\mathrm{ARM} / k$ varies by about a factor of 7 , showing magnetic grain sizes that are not varying greatly (Fig. 3 ).

Beyond characterization of the sediments, paleointensity records must be examined for several additional criteria: records created with different normalizers should be similar; there should be minimal coherence between normalized NRM and the normalizer used; and comparison with other regional paleointensity records should be satisfactory within the limits of the age models [26]. In this regard, we note that (1) the curves for all
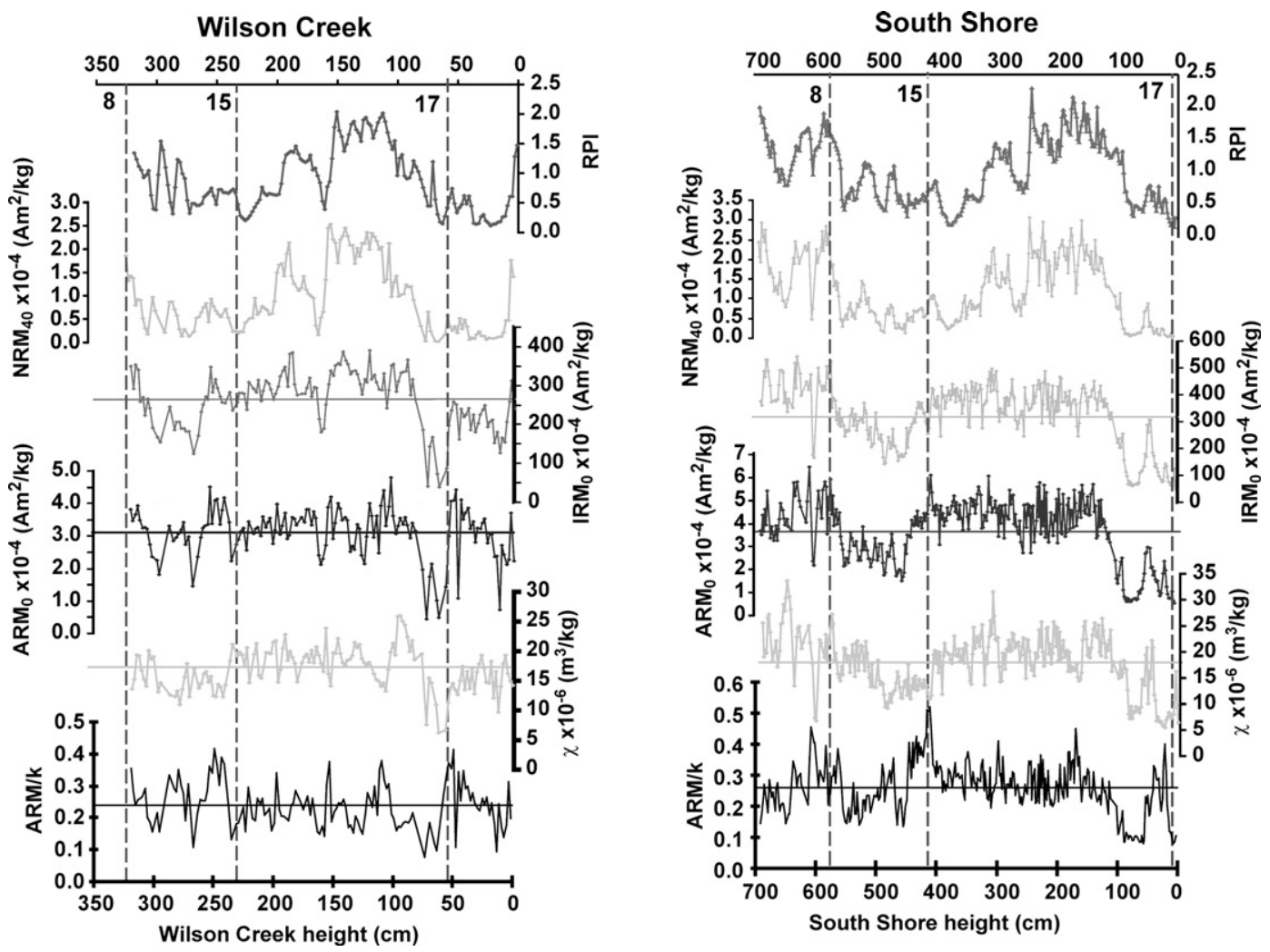

Fig. 3. Relative paleointensity (RPI; $\mathrm{NRM}_{40} / \mathrm{IRM}_{40}$ ), $\mathrm{NRM}_{40}, \mathrm{IRM}_{0}, \mathrm{ARM}_{0}$, and susceptibility $(\chi)$ of the Wilson Creek (left) and South Shore (right) outcrops, on their individual height scales (subscript indicates demagnetization level in $\mathrm{mT}$ ). Ashes 8,15 , and 17 are marked by vertical dashed lines for reference. Susceptibility, ARM, and IRM are important as indicators of magnetite concentration, and for normalizing NRM for paleointensity. Variation of about an order of magnitude or less in $\chi$, ARM, and IRM indicates that magnetite concentration changes are within reasonable limits for paleointensity records [26], and the excellent correspondence of all three parameters in both outcrops demonstrates robustness of the paleointensity signal. Variability of the ratio ARM/k within a factor of 10 indicates magnetite grain size sufficiently uniform for paleointensity [41]. 
three normalizers ( $k$, ARM, IRM) are very similar to each other and between the Wilson Creek and South Shore outcrops (Fig. 3); (2) there is no marked correlation between any normalized record and the normalizer used (all $r^{2}$ values $<0.3$ ); and (3) the normalized curves are very similar in the WC and SS sections (Fig. 3). We have chosen to use NRM/IRM as our relative paleointensity proxy, though the similarity of all the normalizers shows that NRM/ARM and NRM/ $k$ would give equally good results.

\subsection{Creation of a Mono Basin RPI record}

In order to create a composite record of relative paleointensity for correlation to the GLOPIS curve, the Wilson Creek and South Shore outcrop records were correlated in AnalySeries [27] using major ash layers and the bulk susceptibility records, which can be matched at high resolution (Fig. 3). These tie points were applied to the $\mathrm{NRM}_{40} / \mathrm{IRM}_{40}$ (NRM and IRM demagnetized at $40 \mathrm{mT}$ ) records, again resulting in a reasonable match of all features (Fig. 4A).

Each curve was then interpolated at a common sampling interval of $2 \mathrm{~cm}$ (Wilson Creek height), using odd-numbered heights for the Wilson Creek section and even-numbered heights for the South Shore section. This allowed us to integrate the two data sets into a single column, over which we applied a five-point running mean to create the stacked record (Fig. 4B). The averaging of individual records to create a stack is intended to smooth out the local variability in each record (due to non-dipole variations or sedimentary effects) to reveal the "average" global dipole signature [1]. However, some representation of the amount of scatter of the records about the stack is important, and so we have used the standard deviation of the five data points averaged at each level as an indication of the scatter (Fig. 4C).

In the absence of an independent chronology, our regional checks are limited to the excellent agreement between the Wilson Creek and South Shore outcrops, despite different sedimentation rates and variable amounts of authigenic phases. An additional comparison can be made with the paleointensity curve measured by Liddicoat and Coe [3] on the type section outcrop (Fig. 4D). In spite of the fact that the two records were sampled in slightly different parts of the Wilson Creek canyon 30 years apart, and the original samples were fully oriented, the paleointensity records are consistent in even many small-scale features, further increasing our confidence that the Wilson Creek sediments are reliable magnetic field recorders.

\section{Correlation of Mono Basin RPI to the global field signal}

\subsection{Correlation to GLOPIS}

Correlation of the Mono Lake composite record to GLOPIS requires independent age constraints to correctly align the two curves, and we have therefore relied upon previous radiometric age constraints and geological evidence. The agreement between the youngest ${ }^{40} \mathrm{Ar} /{ }^{39} \mathrm{Ar}$ ages for Ash 5, 23.1 $\pm 1.2 \mathrm{ka} \mathrm{[12],}$ and both the leached [10] and unleached [9] radiocarbon ages on proximal sediment indicates that Ash 5 is reliably dated at $22 \mathrm{ka}$ (Fig. 2). Furthermore, although not precisely overlapping within their reported errors, we may assume that the difference between the

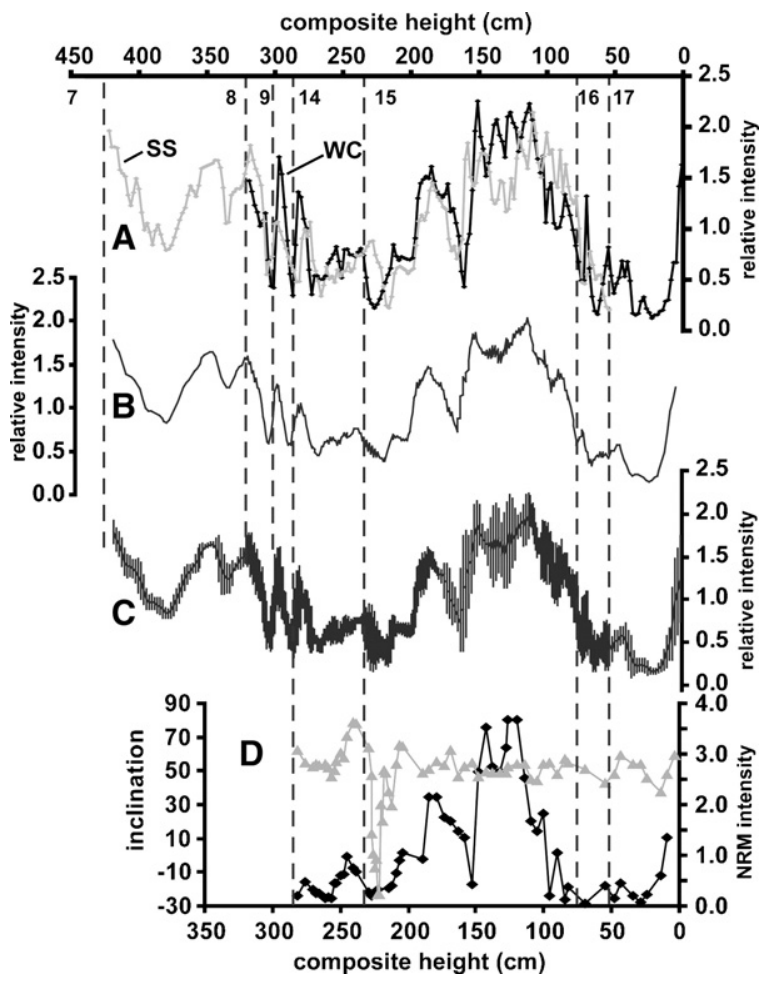

Fig. 4. Creation of the Mono Basin composite paleointensity record. The records of $\mathrm{NRM}_{40} / \mathrm{IRM}_{40}$ represent relative paleointensity (RPI) at the Wilson Creek and South Shore outcrops (A). The South Shore record was correlated to the type section height scale using the tie points established by major ash layers and the susceptibility correlation (Fig. 3). The two records were then normalized to their mean values, interpolated at a common resolution (using AnalySeries [27]), and a 5point running average used to produce the composite record (B). Error envelope on Mono Lake composite record is $1 \sigma$ standard deviation (C). The inclination (triangles) and intensity (diamonds) records of the Mono Lake excursion of Liddicoat and Coe [3] are shown for comparison (D); intensity is $\mathrm{NRM}_{20}$, normalized to the mean for ease of plotting. 
${ }^{40} \mathrm{Ar} /{ }^{39} \mathrm{Ar}$ age $(35.4 \pm 2.8 \mathrm{ka},[12])$ and ${ }^{14} \mathrm{C}$ age $(30.8 \pm$ $0.9,[10])$ of Ash 12 is due to modern carbon contamination and that the age of Ash 12 is $35 \mathrm{ka}$. This approach places Ash 7 (the top of our measured section and $\sim 12 \mathrm{~cm}$ below Ash 5) at $23 \mathrm{ka}$ and Ash 12 at $35 \mathrm{ka}$, resulting in an average sedimentation rate of $16 \mathrm{~cm} / \mathrm{kyr}$ and an extrapolated basal age of $\sim 60 \mathrm{ka}$ for the Wilson Creek Formation (type section) (Fig. 5A).

The leached radiocarbon minimum and $\mathrm{Ar} / \mathrm{Ar}$ maximum age models calculated by Kent et al. [10] yield estimates of the basal age of 46 and $59 \mathrm{ka}$, respectively. To better constrain the age of the base, we use the connection between lake levels in the Great Basin and the SPECMAP 100-kyr climate cycle [28], as demonstrated in neighboring Owens Lake. There, concentrations of $\mathrm{CO}_{3}$ reported from core OL-92, a proxy for lake level, show a clear correlation of lake level over the past 500-ka to the SPECMAP $\delta^{18} \mathrm{O}$ curve, with closed-lake conditions during interglacial periods and glacials represented by an overflowing lake [29]. In accord with this reconstruction is the correlation of the major unconformity in sediments of Pleistocene Summer Lake to the interglacial Marine Isotope Stage (MIS) 5e [30]. We therefore infer that Mono Lake (with the other Great Basin lakes) began to expand at approximately the MIS 5/4 boundary ( $74 \mathrm{ka} ;$ [28]), transgressing the study sites and beginning deposition at some more recent time. Within the constraint of this geologic inference, the broad interval of low RPI near the base of the Mono Lake record is linked with a similar feature centered at $65 \mathrm{ka}$ on the GLOPIS curve (Fig. 5B).

In the interval $23-65 \mathrm{ka}$, the most distinctive feature in the GLOPIS curve is the abrupt, short-lived drop to

GISP2 age (ka)

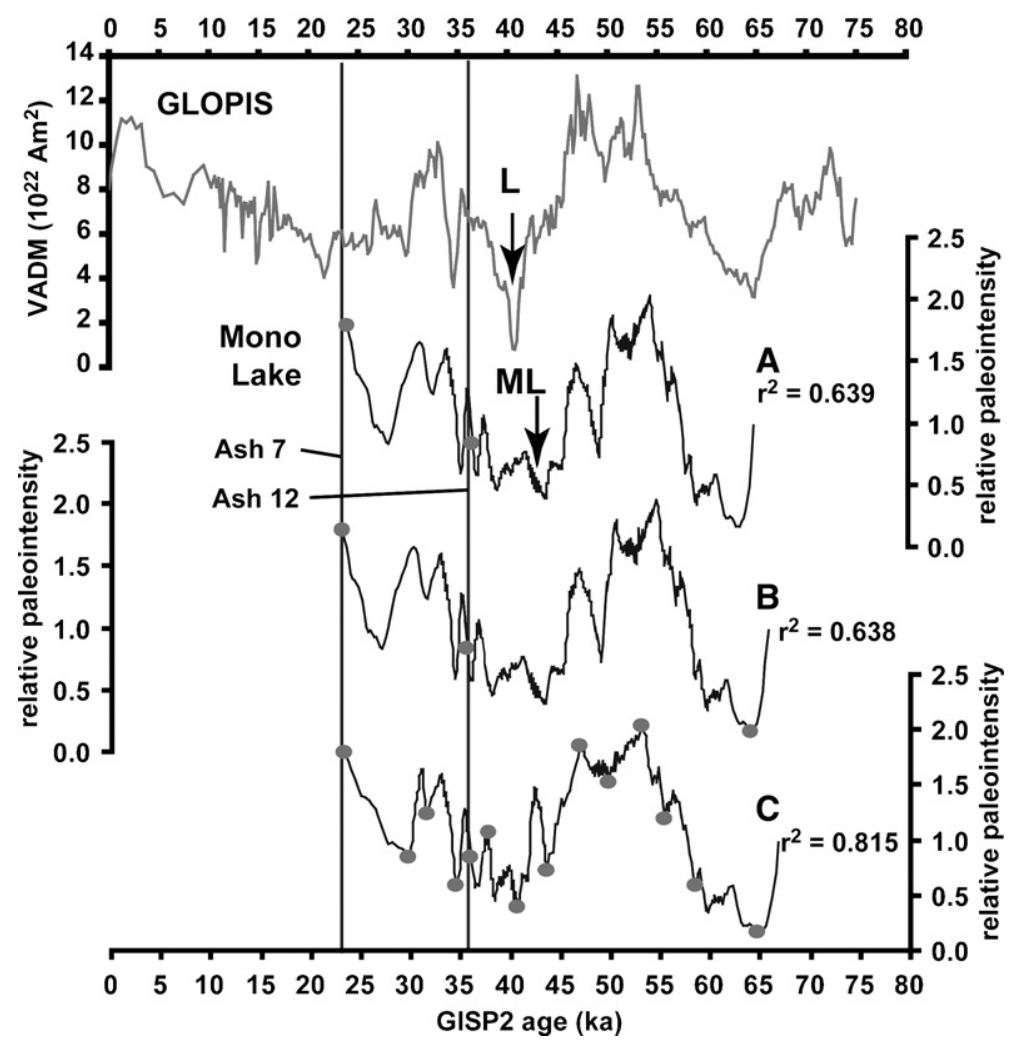

Fig. 5. Correlation of the Mono Lake RPI record with global field signal from the GLOPIS record [1], using AnalySeries [27]. Top panel shows the GLOPIS stack, with the intensity low corresponding to the Laschamp excursion (L) marked by arrow. Correlation using agreement between radiocarbon and $\mathrm{Ar} / \mathrm{Ar}$ ages to pin Ash 7 at $23 \mathrm{ka}$ and Ash 12 at $35 \mathrm{ka}$ (A). Note that these two constraints alone correlate the low at the Mono Lake excursion (ML; arrow) in the Mono Basin record with the Laschamp low in the GLOPIS curve. Correlation (B) adds the inference of lake expansion at MIS 5/4 boundary to tie the broad low near the base of the Mono Lake record to a similar feature at $\sim 65$ ka in GLOPIS. Based on the excellent visual agreement and high correlation coefficient between this model and GLOPIS, we proceed to a final correlation (C), adding eleven tie points based on inflections in the intensity curves. Correlation coefficients calculated by AnalySeries [27] for each version shown to right of curve. Both Mono Lake and GLOPIS are shown without errors, for sake of clarity; see Fig. 6 for error envelopes. 
near-zero paleointensity values at $41 \mathrm{ka}$, the time of the Laschamp excursion. This paleointensity low is expressed in the ${ }^{36} \mathrm{Cl}$ and ${ }^{10} \mathrm{Be}$ records of the Greenland Summit ice cores (GRIP and GISP2) as a large flux peak at $\sim 41 \mathrm{ka}$ (GISP2 age) [31], and the directional excursion itself has been measured in a number of marine sediment cores (e.g., [22]). Climate-based correlations of those cores to the GISP2 ice core also yield an age of $\sim 40 \mathrm{ka}$, with a 1500-yr duration [22], in agreement with the new $\mathrm{K}-\mathrm{Ar}$ and ${ }^{40} \mathrm{Ar} /{ }^{39} \mathrm{Ar}$ estimation of $40.4 \pm 2.0 \mathrm{ka}$ [21]. Both correlation options A and B (Fig. 5) most closely align the feature around Ash 15 at Mono Lake with the Laschamp low at $41 \mathrm{ka}$. This strongly suggests that the directional events recorded at Laschamp and Mono Lake, the only extreme directional change in each record, document the same excursion of the global field.

One striking difference between the Mono Lake record and GLOPIS is the progressive increase in paleointensity recorded at Mono Lake between 30 and $23 \mathrm{ka}$, which is not expressed in the GLOPIS stack during this interval. However, a similar increase exists in the TNO57-21 record (core 21-PC02 of [32]; Fig. 6), suggesting that it may be a subtle variation which is simply smoothed out by the stacking of global records. Alternatively, it is possible that the increase is correlative to the small increase recorded in GLOPIS and NAPIS between 30 and $26 \mathrm{ka}$. Although this violates the Chen et al. [12] ${ }^{40} \mathrm{Ar} /{ }^{39} \mathrm{Ar}$ age for Ash 5, the age of the probability peak for those analyses is $34.5 \mathrm{ka}$, which may be a more robust maximum limit. This would allow the age of Ash 7 at Mono Lake to be $26 \mathrm{ka}$, better aligning the Mono Lake paleointensity increase with the global signal. Fundamentally, the fact that this part of the Mono Lake curve is defined by only one measured section requires that the feature be replicated in another location.

Using the combination of the Ash 7 and Ash 12 radiometric constraints and the geologic inference of transgression, we proceed to refine the correlation of the Mono Lake paleointensity curve with the GLOPIS reference curve, adding additional tie-points at major intensity inflections (total=14; Fig. 5C). The GLOPIS stack was created by correlating each of the 24 individual records to the NAPIS-75 stack [22], producing correlation coefficients between 0.373 and 0.885 , with a mean of 0.701 (Table 1 of Laj et al. [1]). Correlation of the Mono Lake composite record (on the GLOPIS age model constructed here) to the NAPIS-75 stack yields a correlation coefficient of 0.823 , higher than all but three of the GLOPIS records, indicating the compatibility of the Mono Lake curve on our age model with the global signal.

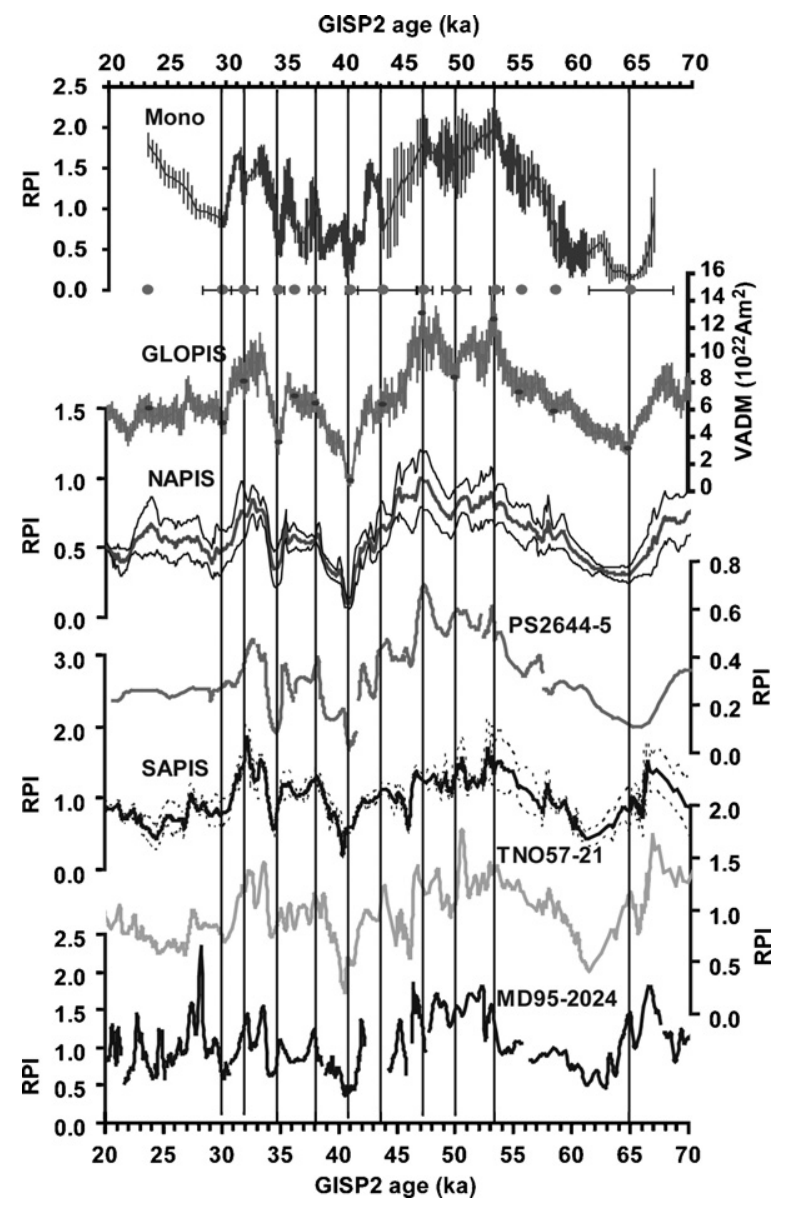

Fig. 6. Comparison of the Mono-GLOPIS correlation with other stacks and records. The North Atlantic Paleointensity Stack (NAPIS) [22] consists of PS2644-5 [37] and five other cores from the North Atlantic; the South Atlantic stack (SAPIS) [32] includes TNO57-21 and four other cores from in and near the Cape Basin. Core TNO57-21 is referred to as 21-PC02 by Stoner et al. [32]. MD95-2024 [36] is a highquality record from the Labrador Sea which is part of GLOPIS but not NAPIS. All records are on the GISP2 age model; differences in the age of the correlated points is due to the differences in shape between the curves. Two-sigma error bars on correlation points (dots), as calculated in Table 2, shown below Mono Lake curve.

\subsection{Rejected correlations}

We have also considered and ultimately rejected correlations of the Mono Lake paleointensity curve to GLOPIS based on the published age model of Benson et al. [23], and on the current estimation of the age of the Mono Lake excursion from correlation to a subsidiary peak in ${ }^{36} \mathrm{Cl}$ production recorded in the GRIP ice core [33]. Retention of the above assumptions of the age of Ash 5 and transgression at the MIS 5/4 boundary, but pinning the low intensity feature at Ash 15 to a GLOPIS subsidiary low at $34 \mathrm{ka}$, produces the correlation in 
Table 1

Paleointensity ages of the Wilson Creek Formation ash beds

\begin{tabular}{|c|c|c|c|c|}
\hline \multirow{2}{*}{$\begin{array}{l}\text { Marker } \\
\text { sequence }\end{array}$} & \multirow{2}{*}{$\begin{array}{l}\text { Ash } \\
\text { bed }\end{array}$} & \multirow{2}{*}{$\frac{\text { RPI age }}{(\mathrm{ka})}$} & \multirow{2}{*}{$\frac{\text { Wilson Creek height }}{(\mathrm{cm})}$} & \multirow{2}{*}{$\frac{\text { South Shore height }}{(\mathrm{cm})}$} \\
\hline & & & & \\
\hline B & 7 & 23.0 & 447 & 694 \\
\hline $\mathrm{C}$ & 8 & 32.8 & 320 & 588 \\
\hline $\mathrm{C}$ & 9 & 35.2 & 298 & 528 \\
\hline $\mathrm{C}$ & 10 & 35.9 & 292 & 500 \\
\hline $\mathrm{C}$ & 11 & 35.9 & 292 & 500 \\
\hline $\mathrm{C}$ & 12 & 36.2 & 290 & 500 \\
\hline $\mathrm{C}$ & 13 & 36.5 & 288 & 500 \\
\hline $\mathrm{C}$ & 14 & 37.1 & 284 & 480 \\
\hline $\mathrm{C}$ & 15 & 39.8 & 238 & 408 \\
\hline D & 16 & 57.5 & 80 & 108 \\
\hline D & 17 & 60.5 & 60 & 0 \\
\hline E & 18 & 66.0 & 10 & \\
\hline E & 19 & 66.0 & 10 & \\
\hline
\end{tabular}

Ages of the Wilson Creek Formation ash beds from the RPI chronology presented here. Marker sequence designations and ash bed numbers are from Lajoie [7], numbered from top (Ash 1; not included in this study) to bottom (Ashes 18/19). Most ash beds are $\leq 1 \mathrm{~cm}$ in the type section; thicker beds (esp. sequence C) were subtracted from the stratigraphy and assigned a single height value. Marker Sequence $C$ beds become very thick $(\geq 10 \mathrm{~cm})$ and coarse (millimeter to centimeter) in the South Shore; therefore, no sediment was sampled between Ash 10 and Ash 13, and those ashes were assigned a single height.

Fig. S2D. An obvious difficulty is the mismatch of high RPI in the Mono Lake record to the Laschamp low at $41 \mathrm{ka}$ in GLOPIS; attempts to get around this produce implausibly large changes in sedimentation rate, for example from $69 \mathrm{~cm} / \mathrm{kyr}$ to $15 \mathrm{~cm} / \mathrm{kyr}$ across the tie point at $33.2 \mathrm{kyr}$ (Fig. S2E).

Another alternative correlation abandons the arguments in section 4.1 and assumes minimal contamination of the published radiocarbon ages $[9,23]$, matching paleointensity features in the Mono Lake curve to GLOPIS within that published chronology (Fig. S2F).
While no dramatic changes in sedimentation rate are required by this version, gross differences in shape appear, such as the correspondence of the steady increase in paleointensity in GLOPIS between 41 and $35 \mathrm{ka}$ to the nearly symmetrical peak in the Mono Lake curve between Ashes 15 and 16.

In addition, all of these correlations indicate that the time interval of the Laschamp excursion is represented by the Wilson Creek Formation, but thorough sampling of the sediments has shown that the Ash 15 excursion is the only large directional excursion recorded [25]. Based on these difficulties with the potential alternatives, and the similarity of even fine details in our initial match, we feel confident that our preferred correlation is the correct one, making the age range of the Wilson Creek Formation 14 to $67 \mathrm{ka}$ (Fig. 5C and Table 1).

\section{Estimation of accuracy and precision}

Because the GLOPIS curve is tied to the GISP2 age model, the accuracy of our new chronology for the Wilson Creek Formation can be no better than that of the ice-core chronology. Errors on that model are quoted as $2 \%$ at $40 \mathrm{ka}$, increasing to at least $5 \%$ at $45 \mathrm{ka}$ and $10 \%$ at $57 \mathrm{ka}$; this gives an absolute error of $6.7 \mathrm{kyr}$ for the oldest part of the Wilson Creek section, at $67 \mathrm{ka}$ [34]. The speleothem record from Hulu Cave, China [35], shows age offsets between the highprecision U-Th ages from Hulu and the GISP2 model of only about $500 \mathrm{yr}$ at $30 \mathrm{ka}$, evidence of the reliability of the GISP2 ages.

The accuracy of our new chronology can also be no better than the accuracy of our correlations to the global paleointensity curve, as represented by GLOPIS. Estimation of the errors introduced by the multiple correlations between the Mono Lake RPI record and the

Table 2

Estimation of age errors on RPI correlation tie-points

\begin{tabular}{|c|c|c|c|c|c|c|c|c|c|c|}
\hline \multirow{2}{*}{$\frac{\text { PI Record }}{\text { GLOPIS }}$} & \multicolumn{10}{|c|}{ GISP2 age of feature (ka) } \\
\hline & 29.8 & 31.8 & 34.6 & 37.8 & 40.8 & 43.6 & 47.0 & 49.8 & 53.2 & 64.6 \\
\hline NAPIS & 28.8 & - & 34.8 & 38.0 & 41.1 & 43.1 & 47.2 & 49.6 & 53.1 & 65.0 \\
\hline SAPIS & 30.7 & 32.7 & 34.3 & 38.4 & 40.5 & 46.1 & - & 51.0 & 53.1 & 61.5 \\
\hline PS2644-5 & 31.3 & - & 34.7 & 38.2 & 40.8 & 43.0 & 47.3 & 49.3 & 53.0 & 65.6 \\
\hline TNO57-21 & 30.3 & 32.8 & 34.3 & 38.7 & 40.5 & - & 46.7 & 49.5 & - & 61.5 \\
\hline MD95-2024 & 30.2 & 32.6 & 34.4 & 38.0 & 40.8 & - & 46.4 & 49.6 & 52.4 & 63.0 \\
\hline Maximum & 31.3 & 32.8 & 34.8 & 38.7 & 41.1 & 46.1 & 47.3 & 51.0 & 53.2 & 65.6 \\
\hline Minimum & 28.8 & 31.8 & 34.3 & 37.8 & 40.5 & 43.0 & 46.4 & 49.3 & 52.4 & 61.5 \\
\hline S.D. & 0.8 & 0.5 & 0.2 & 0.3 & 0.2 & 1.5 & 0.4 & 0.6 & 0.3 & 1.8 \\
\hline
\end{tabular}

Age comparison of GLOPIS [1] tie-points with features in other records, as illustrated in Fig. 6. PS2644-5 [33] and TNO57-21 records are included in NAPIS [28] and SAPIS [34], respectively, and thus in GLOPIS; MD95-2024 [32] is included in GLOPIS. Dashes indicate that a feature cannot be unequivocally identified in a record; the standard deviations of the sets of ages are doubled and applied to the Mono record tie-points as $2 \sigma$ error estimations (e.g., Fig. 6). 
GISP2 chronology is challenging. We have attempted to express the flexibility of our chronology by comparing the ages of our GLOPIS tie-points to the North and South Atlantic stacks (NAPIS and SAPIS [22,32]) and three individual records, MD95-2024 [36], PS2644-5 [37], and TNO57-21 [32] (Fig. 6 and Table 2). The latter two cores are included in the NAPIS and SAPIS stacks, respectively, and thus are also in GLOPIS; PS2644-5 is also the source of the paleoclimate proxy-based correlation between the stacks and GISP2 [37]. MD952024 is a Labrador Sea core for which extensive paleointensity and paleoclimatic work was done [36], and is also included in the GLOPIS stack. Note that all records are shown on the GISP2 age model, and so the differences in age are due to the variability in the shape of each stacked or individual curve.

In general the ages are quite close, with five of the features having standard deviations of less than $500 \mathrm{yr}$, and only two greater than $1000 \mathrm{yr}$. One of these is the sharp drop which occurs just below the Ash 15 intensity low, at $43.6 \mathrm{ka}$; this drop is not well-expressed in either GLOPIS or NAPIS, though much lower-amplitude changes can be identified. In addition, the age of this feature is much older in the SAPIS and TNO57-21 records, resulting in relatively large error bars. Though unfortunately coincident with a core break in MD952024, the original correlation of that record with the GRIP ${ }^{36} \mathrm{Cl}$ (transferred to the GISP2 age model) shows a distinct peak at $44 \mathrm{ka}$, close to our age of $43.6 \mathrm{ka}$ [36].

The other paleointensity feature which is relatively poorly constrained in age is the low between 65 and $60 \mathrm{ka}$, which is well-expressed in most paleointensity and cosmogenic nuclide records. In part this poor age control is due to the differing shapes; some records show a steep drop to low values before a symmetric recovery (as in TNO57-21), while others merely relax to a broad low without a distinctive minimum (as in PS2644-5). These differences produce a two-sigma error of $3.6 \mathrm{kyr}$ near the base of the Wilson Creek Formation (Fig. 6). This time interval is unfortunately extremely difficult to date accurately and precisely in general, as it is beyond the range of radiocarbon dating and the high-frequency climatic events which make long-distance correlations possible in MIS 3 are much more rare in MIS 4.

\section{Implications for previous radiometric age models}

\subsection{Radiocarbon dating}

Comparison of our new paleointensity-based age model with the previous radiocarbon ages reveals differences of as much as $25 \mathrm{kyr}$ at the base of the section, a very large change in age for late Pleistocene sediments. However, four studies have now demonstrated the unreliability of radiocarbon ages measured on carbonates from the Great Basin. In addition to the leaching results discussed above [10,11], Lao and Benson [38] found good agreement between ${ }^{230} \mathrm{Th}$ and ${ }^{14} \mathrm{C}$ ages for gastropods of $12 \mathrm{ka}$ to $20 \mathrm{ka}$ from Pyramid Lake, but measured a ${ }^{230} \mathrm{Th}$ age of $49 \pm 5 \mathrm{ka}$ for Walker Lake gastropods with ${ }^{14} \mathrm{C}$ ages of $28.7 \pm 0.6 \mathrm{ka}$. Furthermore, Lin et al. [39] measured ${ }^{230} \mathrm{Th}$ and ${ }^{14} \mathrm{C}$ ages in carbonates from the Lahontan basins, and found offsets of 1-2 kyr even at 16-20 ka.

In fact, model calculations demonstrate that even $1 \%$ modern carbon added to a $40 \mathrm{ka}$ sample produces a bias of $>5 \mathrm{kyr}$, more than doubling to $12 \mathrm{kyr}$ by $50 \mathrm{ka}$ (Fig. S3). Beyond that point (assuming perfect analytical capabilities), any sample with $1 \%$ modern carbon contamination will appear to be 39 to $41 \mathrm{ka}$, regardless of the geological age of the sample. The distribution of the unleached ages $[9,23]$ on this plot shows that most require only about $1.5 \%$ contamination with modern carbon to produce the observed age offset. The oldest leached ages [10] fall closer to the $0.5 \%$ contamination line, demonstrating that the progressive leaching technique can reduce, but perhaps not always eliminate, the modern carbon problem. This exercise emphasizes the tiny amounts of contamination required to produce ages much too young, as well as the dangers of relying on carbonate radiocarbon ages so many times the halflife of ${ }^{14} \mathrm{C}$, even where analytical limits allow apparently precise ages to be calculated.

\subsection{Ar/Ar dating}

Our RPI-based chronology conforms to all the previous $\mathrm{Ar} / \mathrm{Ar}$ age constraints with one apparent exception, the interpreted ${ }^{40} \mathrm{Ar} /{ }^{39} \mathrm{Ar}$ age of Ash 16 (Fig. S4) [10]. According to the hypothesis that the age of the youngest population of sanidines is a maximum limit on the age of that stratigraphic level, our paleointensitybased estimate, $57.4 \mathrm{ka}$, is too old by $6 \mathrm{kyr}$. However, reexamination of the probability distribution of the Ash 16 analyses (Fig. 7A) reveals a single peak at $64.9 \mathrm{ka}$ formed by 22 of 40 analyses, half with analytical errors $<5$ kyr. In contrast, the dates that were chosen by the authors [10] as the maximum age estimate represent only 5 of the 40 analyses, with errors of 6 to 12 kyr. Moreover, the probability curve of our new Ash 16 analyses shows a double peak, at $64.2 \mathrm{ka}$ and $72.8 \mathrm{ka}$ (Fig. 7B; Supplemental Table 1). We therefore suggest that a peak age of 64-65 ka is a more robust maximum limit for Ash 16, thus permitting the RPI age of $57.4 \mathrm{ka}$. 
A
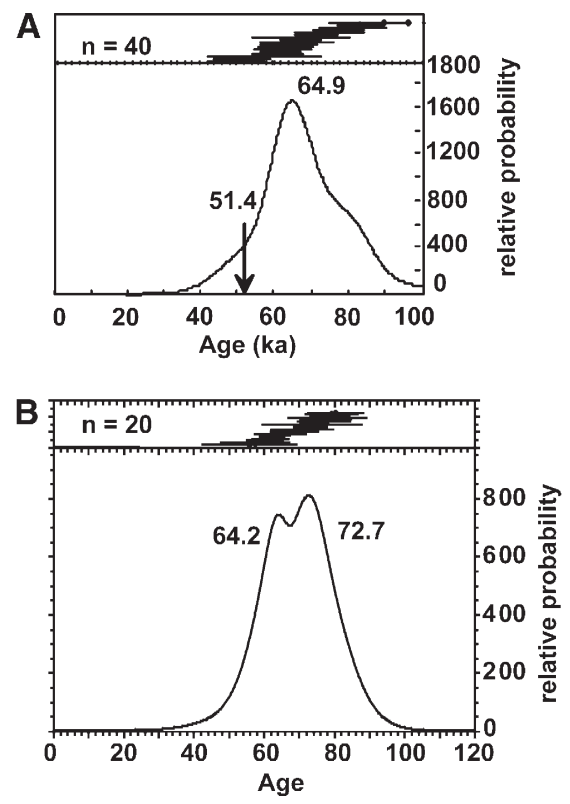

Fig. 7. Probability plots of all Ash $16^{40} \mathrm{Ar}{ }^{39}$ Ar analyses. (A) Published results of Kent et al. [10] shows that the peak of $65 \mathrm{ka}$ is defined by 22 of the 40 analyses, with much smaller analytical errors than the 5 analyses representing the $51.4 \mathrm{ka}$ population. This suggests that a maximum limit of 65 ka more robustly represents the Ash 16 analyses, in good agreement with the paleointensity-based age of $57.4 \mathrm{ka}$. (B) New results from sanidines picked from crushed pumice fragments, showing two peaks at $64.2 \mathrm{ka}$ and $72.7 \mathrm{ka}$, consistent with the interpreted maximum limit of 65 ka for Ash 16. Data from (B) are in Supplemental Table 1.

\section{Implications for the Mono Basin lake-level record}

The well-exposed Wilson Creek Formation holds the potential for high-resolution climatic records of lakelevel, tied to snowfall in the Sierras and evaporation over the basin, and the dynamics and sediment production of the Sierran valley glaciers. For example, comprehensive examination of facies changes in outcrops around the Mono Basin allowed Lajoie [7] to create a curve of lake-level changes during Wilson Creek time, showing three periods of relatively high lake level. In addition, Benson et al. [23] published composite records of carbonate content and bulk $\delta^{18} \mathrm{O}$ from the type and South Shore sections, which show millennial-scale changes in hydrological conditions.

With application of the new RPI chronology, these records can now be tied to the global framework of glacial-interglacial cycles and the developing picture of millennial-scale variability during MIS 3 (Fig. 8). The large change in the basal age of the Wilson Creek Formation naturally leads to equally large changes in the correlations of paleoclimate records from those sediments. For example, we find that the three peaks in lake level indicated by the stratigraphic evidence and sediment carbonate content clearly align with the three peaks (and subsequent decreases) in local spring insolation at $15 \mathrm{ka}, 39 \mathrm{ka}$, and $64 \mathrm{ka}$ (Fig. 8). This

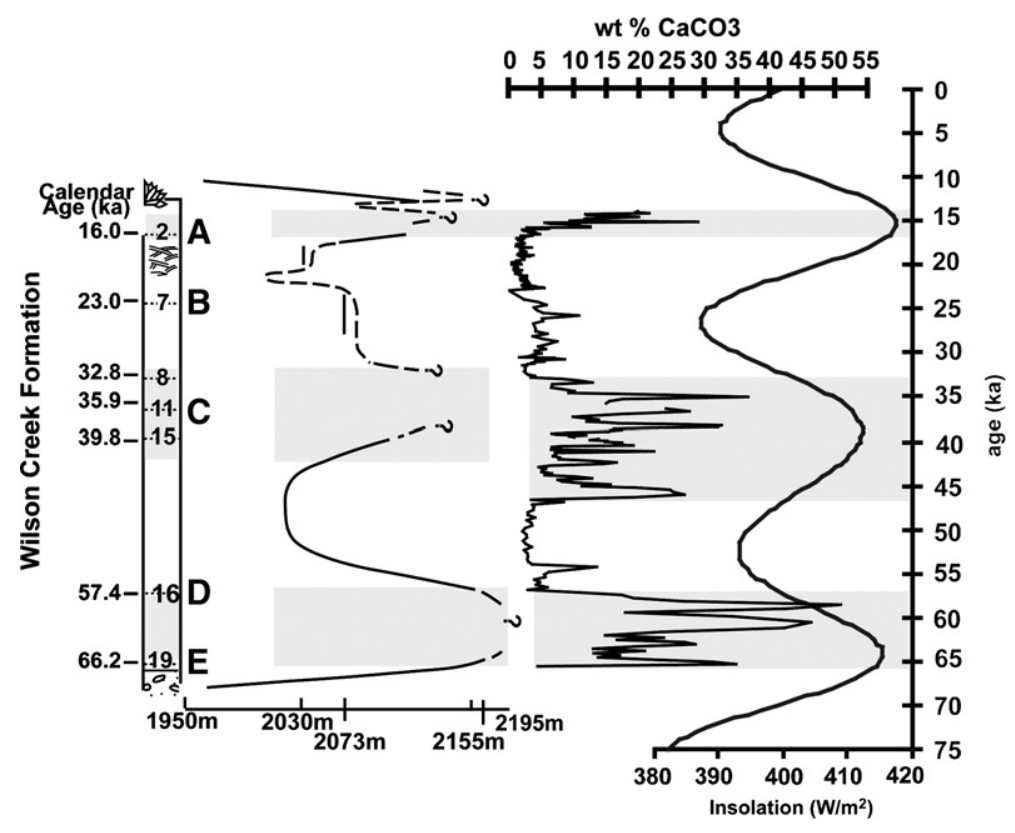

Fig. 8. Simplified stratigraphic column and lake level curve of Lajoie [7] and \% Total Inorganic Carbon (shown here as weight \% carbonate) curve of Benson et al. [23] for the Wilson Creek Formation, all on the new RPI age model. Gray bars mark periods of inferred high lake levels, which correspond to peaks in spring insolation (Mar-Apr-May) [42] at the latitude of Mono Lake $\left(38^{\circ} \mathrm{N}\right)$. 
correlation highlights the importance to Mono Lake level of the spring season, when melting of winter snows in the Sierras produces peak flows in the mountain streams, the dominant hydrological input to the basin [40].

\section{Conclusions}

Our study of relative paleointensity at Mono Lake produces several important results. The most widely significant is the demonstration that the high-resolution global paleointensity record, which has now been measured in many marine sediment cores, can also be reproduced in lacustrine sediments that have been carefully examined for suitability as magnetic field recorders. Significantly, we have demonstrated that sediments which have been shown to be accurate paleo-field recorders need not be freshly cored or sampled specifically for paleointensity. This should allow the global reference curve to be applied to many long lake records which are currently unreliably or insufficiently dated, with the result that many existing Pleistocene terrestrial paleoclimate records can potentially be considered in the millennial-scale global framework.

More specifically, we have developed a highresolution chronology for the Wilson Creek Formation at Mono Lake. Unlike the existing radiocarbon dates, the accuracy of our control points is limited primarily by the errors on the GISP2 age model, with a small additional uncertainty due to correlation of features between individual records. This means that correlation of Wilson Creek paleoclimate records to any other record on the GISP2 chronology is limited by errors of $1-3 \mathrm{kyr}$, a vast improvement over the previous age control.

Furthermore, the correspondence between the Mono Lake-level curve on our new timescale and regional and global indicators of glacial-age paleoclimate strongly suggests that the Wilson Creek Formation began to be deposited more than $20 \mathrm{kyr}$ earlier than previously thought, and records climate change for much of MIS 4, all of MIS 3, and most of MIS 2. This increase in the duration of the expanded Mono Lake to cover most of the last glacial period is much more parsimonious than the previous age model, which requires a climatic trigger at $\sim 40$ ka to dramatically expand the lake, where no such change is apparent in global records. Two other wellstudied lacustrine sequences in the West also cover the last glaciation, Owens Lake to the south and Summer Lake to the north: the addition of the Wilson Creek records fills an important spatial gap and will potentially allow the detection of patterns in temperature and precipitation in the western U.S. during the last glaciation.

Finally, we have shown that the best correlation of the Mono Lake paleointensity record to the global reference curve aligns the Ash 15 directional excursion (i.e., what has been called the "Mono Lake Excursion") with the global Laschamp excursion at $41 \mathrm{ka}$, making Mono Lake perhaps the first location in North America where the Laschamp has been recognized. We suspect that reevaluation of paleointensity curves and age control of other locations in the Great Basin during the last glacial period will reveal other records of the Laschamp excursion.

\section{Acknowledgements}

Collection of paleomagnetic data for this study was ably supplemented by C. Mason; fieldwork was greatly assisted by K. Tamulonis, and funded by grants from The Geological Society of America and The Climate Center Committee of LDEO. Discussions with B. Turrin, C. Laj, W. Broecker, N. Shackleton, A. Piotrowski, and S.Stine helped to sharpen our thinking, and L. Benson, C. Laj, C. Kissel, J. Stoner, and A. Voelker generously provided data; all are gratefully acknowledged. Thanks to C Laj., L. Tauxe, and the editor (P. Delaney) for reviews and comments which helped us to substantially improve the manuscript. This material is based upon work supported under a National Science Foundation Graduate Research Fellowship. This is LDEO Contribution\#

\section{Appendix A. Supplementary data}

Supplementary data associated with this article can be found, in the online version, at doi:10.1016/j. eps1.2006.09.030.

\section{References}

[1] C. Laj, C. Kissel, J. Beer, High resolution global paleointensity stack since $75 \mathrm{kyr}$ (GLOPIS-75) calibrated to absolute values, in: J.E.T. Channell, D.V. Kent, W. Lowrie, J.G. Meert (Eds.), Timescales of the Paleomagnetic Field, Geophysical Monograph, vol. 145, American Geophysical Union, Washington, D.C., 2004, pp. 255-265.

[2] C.R. Denham, A. Cox, Evidence that the Laschamp polarity event did not occur 13,300-34,000 years ago, Earth Planet. Sci. Lett. 13 (1971) 181-190.

[3] J.C. Liddicoat, R.S. Coe, Mono Lake geomagnetic excursion, JGR 84 (1979) 261-271.

[4] S. Baumgartner, J. Beer, J. Masarik, G. Wagner, L. Meynadier, H.-A. Synal, Geomagnetic modulation of the $36 \mathrm{Cl}$ flux in the GRIP ice core, Greenland, Science 279 (1998) 1330-1332.

[5] S. Levi, R. Karlin, A sixty thousand year paleomagnetic record from Gulf of California sediments: secular variation, Late Quaternary excursions and geomagnetic implications, Earth Planet. Sci. Lett. 92 (1989) 219-233.

[6] R.M. Negrini, D.B. Erbes, K. Faber, A.M. Herrera, A.P. Roberts, A.S. Cohen, P.E. Wigand, J. Franklin, F. Foit, A paleoclimate record for the past 250,000 years from Summer Lake, Oregon, 
USA: I. Chronology and magnetic proxies for lake level, J. Paleolimnol. 24 (2000) 125-149.

[7] K.R. Lajoie, Quaternary Stratigraphy and Geologic History of Mono Basin, Eastern California, Ph.D., University of California, 1968.

[8] R.G. Fairbanks, R.A. Mortlock, T.-C. Chiu, L. Cao, A. Kaplan, T.P. Guilderson, T.W. Fairbanks, A.L. Bloom, P.M. Grootes, M.-J. Nadeau, Radiocarbon calibration curve spanning 0 to 50,000 years BP based on paired ${ }^{230} \mathrm{Th} /{ }^{234} \mathrm{U} /{ }^{238} \mathrm{U}$ and ${ }^{14} \mathrm{C}$ dates on pristine corals, QSR 24 (2005) 1781-1796.

[9] L.V. Benson, D.R. Currey, R.I. Dorn, K.R. Lajoie, C.G. Oviatt, S.W. Robinson, G.I. Smith, S. Stine, Chronology of expansion and contraction of four Great Basin lake systems during the past 35,000 years, Palaeogeogr. Palaeoclimatol. Palaeoecol. 78 (1990) 241-286.

[10] D.V. Kent, S.R. Hemming, B.D. Turrin, Laschamp excursion at Mono Lake? Earth Planet. Sci. Lett. 197 (2002) 151-164.

[11] I. Hajdas, G. Bonani, S.H. Zimmerman, M. Mendelson, S. Hemming, C-14 ages of ostracodes from Pleistocene lake sediments of the western Great Basin, USA-Results of progressive acid leaching, Radiocarbon 46 (2004) 189-200.

[12] Y. Chen, P.E. Smith, N.M. Evensen, D. York, K.R. Lajoie, The edge of time: dating young volcanic ash layers with the ${ }^{40} \mathrm{Ar}-{ }^{39} \mathrm{Ar}$ laser probe, Science 274 (1996) 1176-1178.

[13] N. Bonhommet, J. Zahringer, Paleomagnetism and potassium argon age determinations of the Laschamp geomagnetic polarity event, Earth Planet. Sci. Lett. 6 (1969) 43-46.

[14] P.Y. Gillot, J. Labeyrie, C. Laj, G. Valladas, G. Guerin, G. Poupeau, G. Delibras, Age of the Laschamp paleomagnetic excursion revisited, Earth Planet. Sci. Lett. 42 (1979) 444-450.

[15] C.M. Hall, D. York, $\mathrm{K}-\mathrm{Ar}$ and ${ }^{40} \mathrm{Ar} /{ }^{39} \mathrm{Ar}$ age of the Laschamp geomagnetic polarity reversal, Nature 274 (1978) 462-464.

[16] M. Condomines, Age of the Olby-Laschamp geomagnetic polarity event, Nature 276 (1978) 257-258.

[17] G. Guerin, G. Valladas, Thermoluminescence dating of volcanic plagioclases, Nature 286 (1980) 697-699.

[18] L.V. Benson, J. Liddicoat, J. Smoot, A. Sarna-Wojcicki, R. Negrini, S.P. Lund, Age of the Mono Lake excursion and associated tephra, QSR 22 (2003) 135-140.

[19] J.C. Liddicoat, Mono Lake excursion in Mono Basin, California, and at Carson Sink and Pyramid Lake, Nevada, Geophys. J. Int. 108 (1992) 442-452.

[20] J.C. Liddicoat, Mono Lake excursion in the Lahontan Basin, Nevada, Geophys. J. Int. 125 (1996) 630-635.

[21] H. Guillou, B.S. Singer, C. Laj, C. Kissel, S. Scaillet, B.R. Jicha, On the age of the Laschamp geomagnetic excursion, Earth Planet. Sci. Lett. 227 (2004) 331-343.

[22] C. Laj, C. Kissel, A. Mazaud, J.E.T. Channell, J. Beer, North Atlantic paleointensity stack since $75 \mathrm{ka}$ (NAPIS-75) and the duration of the Laschamp event, Philos. Trans. R. Soc. Lond., A 358 (2000) 1009-1025.

[23] L.V. Benson, S.P. Lund, J.W. Burdett, M. Kashgarian, T.P. Rose, J.P. Smoot, M. Schwartz, Correlation of Late-Pleistocene lakelevel oscillations in Mono Lake, California, with North Atlantic climate events, QR 49 (1998) 1-10.

[24] L. Benson, S. Lund, R. Negrini, B. Linsley, M. Zic, Response of the North American Great Basin lakes to Dansgaard-Oeschger oscillations, QSR 22 (2003) 2239-2251.

[25] S.P. Lund, J.C. Liddicoat, K.R. Lajoie, T.L. Henyey, S.W. Robinson, Paleomagnetic evidence for long-term ( $10^{4}$ year $)$ memory and periodic behavior in the Earth's core dynamo process, Geophys. Res. Lett. 15 (1988) 1101-1104.
[26] L. Tauxe, Sedimentary records of relative paleointensity of the geomagnetic field: theory and practice, Rev. Geophys. 31 (1993) 319-354

[27] D. Paillard, L. Labeyrie, Macintosh program performs timeseries analysis, Eos, Trans., AGU 77 (1996) 379.

[28] D.G. Martinson, N.G. Pisias, J.D. Hays, J. Imbrie, J. Theodore, C. Moore, N.J. Shackleton, Age Dating and the orbital theory of the ice ages: development of a high-resolution 0 to 300,000-year chronostratigraphy, QR 27 (1987) 1-29.

[29] J.L. Bischoff, J.P. Fitts, J.A. Fitzpatrick, Responses of sediment geochemistry to climate change in Owens Lake sediment: an 800k.y. record of saline/fresh cycles in core OL-92, in: G.L. Smith, J. L. Bischoff (Eds.), An 800,000-Year Paleoclimatic Record from Core OL-92, Owens Lake, Southeast California, 1997.

[30] A.S. Cohen, M.R. Palacios-Fest, R.M. Negrini, P.E. Wigand, D.B. Erbes, A paleoclimate record for the past 250,000 years from Summer Lake, Oregon, USA: II. Sedimentology, paleontology and geochemistry, J. Paleolimnol. 24 (2000) 151-182.

[31] R. Muscheler, J. Beer, P.W. Kubik, H.-A. Synal, Geomagnetic field intensity during the last 60,000 years based on $10 \mathrm{Be}$ and $36 \mathrm{Cl}$ from the Summit ice cores and 14C, QSR 24 (2005) $1849-1860$.

[32] J.S. Stoner, C. Laj, J.E.T. Channell, C. Kissel, South Atlantic and North Atlantic geomagnetic paleointensity stacks $(0-80 \mathrm{ka})$ : implications for inter-hemispheric correlation, QSR 21 (2002) $1141-1151$

[33] G. Wagner, J. Beer, C. Laj, C. Kissel, J. Masarik, R. Muscheler, H.-A. Synal, Chlorine-36 evidence for the Mono Lake event in the Summit GRIP ice core, Earth Planet. Sci. Lett. 181 (2000) 1-6.

[34] D.A. Meese, A.J. Gow, R.B. Alley, G.A. Zielinski, P.M. Grootes, M. Ram, K.C. Taylor, P.A. Mayewski, J.F. Bolzan, The Greenland Ice Sheet Project 2 depth-age scale; methods and results, JGR 102 (1997) 26411-26423.

[35] Y.J. Wang, H. Cheng, R.L. Edwards, Z.S. An, J.Y. Wu, C.-C. Shen, J.A. Dorale, A high-resolution absolute-dated Late Pleistocene monsoon record from Hulu Cave, China, Science 294 (2001) 2345-2348.

[36] J.S. Stoner, J.E.T. Channell, C. Hillaire-Marcel, C. Kissel, Geomagnetic paleointensity and environmental record from Labrador Sea core MD95-2024: global marine sediment and ice core chronostratigraphy for the last $110 \mathrm{kyr}$, Earth Planet. Sci. Lett. 183 (2000) 161-177.

[37] A.H.L. Voelker, M. Sarnthein, P.M. Grootes, H. Erlenkeuser, C. Laj, A. Mazaud, M.-J. Nadeau, M. Schleicher, Correlation of marine $14 \mathrm{C}$ ages from the Nordic Seas with the GISP2 isotope record: implications for the $14 \mathrm{C}$ calibration beyond $25 \mathrm{ka} \mathrm{BP}$, Radiocarbon 40 (1998) 517-534.

[38] Y. Lao, L. Benson, Uranium-series age estimates and paleoclimatic significance of Pleistocene tufas from the Lahontan Basin, California and Nevada, QR 30 (1988) 165-176.

[39] J.C. Lin, W.S. Broecker, R.F. Anderson, S. Hemming, J.L. Rubenstone, G. Bonani, New ${ }^{230} \mathrm{Th} / \mathrm{U}$ and ${ }^{14} \mathrm{C}$ ages from Lake Lahontan carbonates, Nevada, USA, and a discussion of the origin of initial thorium, GCA 60 (1996) 2817-2832.

[40] P.T. Vorster, A Water Balance Forecast Model for Mono Lake, California State University, California, 1985.

[41] J.W. King, S.K. Banerjee, J. Marvin, A new rock-magnetic approach to selecting sediments for geomagnetic paleointensity studies: application to paleointensity for the last 4000 years, JGR 88 (1983) 5911-5921.

[42] A.L. Berger, Long-term variations of daily insolation and Quaternary climatic changes, J. Atmos. Sci. 35 (1978) 2362-2367. 